\author{
Dariusz Lipiec* \\ The John Paul II Catholic University of Lublin, Poland
}

\title{
Parish Pastoral Care and Families of the Disabled
}

A parish is part of God's people who are seeking salvation under the leadership of the parish priest as their shepherd. It is a place where believers meet $\mathrm{God}^{1}$. There they hear the Word of God, which gathers them into a community and leads them in their earthly existence. In the parish, believers receive Sacraments which deepen their union with Christ and with one another, and which, at the same time, strengthen them in various situations. In the parish, Christians seek their full salvation, which they hope to achieve in eternity. The parish community is based on faith, hope and love. Christian love, described as brotherly love, is the law of the parish. Community, as well, is the fundamental principle of the mutual relationships of its members ${ }^{2}$.

This Christian brotherly love is addressed to every person. In particular, there is the principle of the Christian charity towards the weak. In the Church, it is reflected in the special care for the poor. The 'poor' are not only the people affected by material poverty but all those who are in need of help: the sick, the old, social

* DARIUSZ LIPIEC - is an assistant professor of Pastoral Theology, a priest of the diocese of Siedlce, the head of the Chair of Organization of Pastoral Care at the Catholic University of Lublin, a member of: the Scientific Society of the Catholic University of Lublin, The Polish Pastoral Priests Society, PostNetzwerks der mittel- und osteuropäischen Pastoraltheologinnen und Pastoraltheologen; the author of the book Duszpasterstwo niewidomych i słabowidzacych w Polsce. Studium teologicznopastoralne (Lublin 2011) (The pastoral care of the blind and the visually impaired in Poland. The theological and pastoral study) as well as the author of many articles on the pastoral theology, especially on the lay apostolate and the pastoral care of the disabled.

1 CIC, can. $515 \S 1$.

2 R. Kamiński, Działalność zbawcza Kościoła w teorii i praktyce pastoralnej, Lublin 2007, Wydawnictwo KUL, p. 158-161. 
misfits, people with disabilities and other "weak" people. Since a parish's role is to establish and develop the bonds between the faithful and God and between one another, all the weak people are of the primary concern, especially the disabled. A parish is a place of the ecclesial integration of such people and pastoral work of the Church is its essential service addressed to the people suffering from disabilities.

\section{Disability and the life in a marriage and family}

Disability is a congenital or acquired limitation in the development of a human being, in his mobility, or mental and sensory functioning, which prevents his normal functioning in the social, cultural and religious life ${ }^{3}$. It influences the functioning of a marriage and a family from the very beginning. It influences the decision of contracting a marriage. The situation of a disabled person who wants to start a family is more complex than the situation of an able-bodied person. Physical or mental limitations, especially if they are of more than the moderate extent, impede undertaking the obligations which result from marriage and parenting. This means that a large part of the responsibility must be taken by the able-bodied spouse, which is associated with an additional burden. In many cases, the marriage and the family of a disabled person needs the assistance of other people, especially distant relatives, which indicates the dependence of the couple. What is more, disability is connected with the difficulties in finding a job, which leads to the situation in which a significant percentage of disabled people support their families and themselves only through the social benefits. These and other similar effects of disability result in perceiving a person so affected, as a less attractive candidate for a marriage.

Disability influences the permanence of a marriage. Marriages in which the disability of one spouse occurred before the wedding are usually more indissoluble than those in which the disability occurred while it lasted. Able-bodied people are usually more conscious of the consequences of marrying a disabled person and life in a marriage with such a person is not a source of surprising situations for them. There are, however, people who are not able to deal with the everyday life shared with a disabled person. What is more, among the disabled there are those who made the decision to get married too hastily ${ }^{4}$.

\footnotetext{
3 See A. Kiciński, Niepetnosprawny, in: Encyklopedia Katolicka, vol. 13, col. 1153-1154.

4 See J. Kawka, Warunki wychowawcze dzieci w rodzinach inwalidów wzroku, Lublin 1996, Wydawnictwo UMCS, p. 25-26.
} 
The situation is different in such marriages, in which one of the spouses became disabled throughout the marriage. Neither those spouses who became disabled nor their partners were prepared for the situation. Disability often occurs suddenly, as a result of random accidents. The difficulties, in functioning of such families concern both spouses. In the beginning, people affected by disability rebel against it, which makes coping with the situation even more difficult. This leads to a difficulty in revising the current position in the marriage and family and in taking the roles of the spouse and parent in a new way.

The difficulties which concern the able-bodied spouse also result from the inability to accept the disability of the partner. The occurrence of their disability is often perceived by them as an anticlimax in their life. The lack of acceptance of the disability of the spouse is often transferred to the disabled spouse, which leads to the rejection of the latter and then to the dissolution of such a marriage. A partial acceptance of the disability of the spouse may lead to the weakening of the marriage bond, to the lack of adequate support for the disabled, to the marginalization of the disabled person in the community of the family and to other negative effects. However, it should be noted that the relationship of the spouses after the occurrence of the disability is related to the previous quality of their marriage: the more stable the marriage bonds, the more positive is the attitude towards the disabled.

Marriages of two disabled people are an exceptional situation. Their situation depends on the kind of disability, its extent and the level of rehabilitation. Marriages with a low level of disability of the spouses, and those who are the best rehabilitated, are the most independent and they require the least help from others. Statistically, there are fewer marriages between two disabled people than those in which only one spouse is disabled. There are more marriages in which the spouses suffer from the same kind of disability than those with different disabilities ${ }^{5}$.

Having children is one of the most important reasons of contracting a marriage by the disabled people. Many of them believe that children are a natural result of their marriage and therefore, they consider the time before having children as transitional. For many disabled people having children is the main aim of their marriage. For most of them, it is the result of the mutual love of the spouses and a means of strengthening their marriage. Having children contributes to satisfying psychological needs and is the source of joy and satisfaction. Some disabled parents treat their children as a redress of their unfulfilled dreams and plans or as

5 See S. Kotowski, Pomyślmy i porozmawiajmy o naszych sprawach, Warszawa 1994, ZG PZN, p. $82-84$. 
an extension of their life. Sometimes such a child is treated instrumentally by the disabled parents, as their protection from loneliness and old age or as a source of aid in their everyday life ${ }^{6}$.

The fertility of the disabled depends on different factors. It is conditioned by the health condition of the spouses, their living and material conditions, the possibility to receive the support from the community, etc. There are also such marriages who decide not to have children. The most common reason for that is the health condition of the spouses, especially of the woman. Another reason is the fear that the child will inherit the disability, especially when it is genetically determined. Yet another reason could be that the illness, especially if serious concerns one or both of the spouses, or can lead to an additional disability. Some other reason to refrain from procreating is the difficult living conditions: the lack of a flat or a flat that lacks proper adaptation to the needs of a disabled person and to bringing up a child. Additionally, there is the reason of the financial condition of the spouses. However, the financial difficulties are mostly the reason for limiting the number of children and not for refraining from it ${ }^{7}$. The issue of procreation is closely connected with the issue of birth control, with the special emphasis on the problem of abortion. The disabled spouses decide to have an abortion mostly when the pregnancy leads to the further deterioration of the health of the woman, when the family is in a difficult living condition and when there is no support in the education of children. Single disabled women also decide to have an abortion.

Disability negatively influences the educating and caring function of the family. The damage of the senses or the mobility makes it more difficult to bring up a child and to take good care of him or her. This can lead to overprotection, when the parents try to compensate for the lack of care thus limiting the independence of the child. The disability of parents can result in paying too much attention to the health condition of the child ${ }^{8}$.

Sensory or mental disability of the parents can negatively influence the child's education. Such a child is not able to rely on his or her parents in such situations

6 K. Błeszyńska, Wartość miłości, małżeństwa i rodziny w życiu osób niepetnosprawnych, Warszawa 1994, Żak, p. 144.

7 See J. Kawka, Warunki wychowawcze dzieci w rodzinach inwalidów wzroku, Lublin 1996, Wydawnictwo UMCS, p. 84-86.

8 See A. Zajączkowska, Niewidoma matka - pieleggnacja niemowlęcia, "Nasze Dzieci” (2005) nr 10, p. 13-14. 
as e.g. doing homework to the same extent as a child of able-bodied parents. These children are required to rely mostly on themselves to a greater extent than children of able-bodied parents. Disabled parents are not fully able to monitor the child's progress in learning. It is necessary for them to cooperate with the teachers and tutors at school. In order to ensure the adequate level of education and the proper upbringing of their children they must rely on other people's help. The extracurricular classes, participation in the children's or youth organizations etc. are of crucial importance for the children who are born in the families of the disabled than for those who have able-bodied parents.

Disability influences the religious life of a person in its four dimensions: the cognitive and existential, the emotional and motivational, the expressive. and the executive. In the cognitive and existential aspect, the problem of the meaning of disability is of the primary importance. The question "Why me?", for disabled people who were born with a disability, arises in the period of adolescence, with the deepening of self-awareness. On the other hand it arises in adulthood, after the occurrence of disability. This question is posed mostly on the basis of religion, because science can give detailed answers relating to the condition. With the occurrence of the disability, disabled people experience difficulties with perceiving God as the Father who wants the good for His children. Realizing his or her inferiority, the disabled person experiences difficulties with perceiving the Church as a community based on the mutual brotherly love.

In the emotional and motivational aspect, religiousness plays a positive role in the life of a disabled person. It helps to reconcile with the disability. However, the full reconciliation with one's disability is not possible, because it is not a benefit to a human being but it means the lack of something in life. However, a partial affirmation, that allows for the process of a revalidation or rehabilitation. is possible. Such a reconciliation makes it possible for a disabled person to find the meaning in life, as well as his or her own vocation and self-confidence.

The negative influence of the disability on a person's religiousness is also noticeable in the expressive and executive aspects of religiousness. According to the kind and level of disability a person suffers from, it is more difficult for him or her to participate in the life of the Church as a community of believers, especially in the parish. Disability is the source of limitations in satisfying personal religious needs in the life of a person: in listening to and preaching the Word of God, in participation in the liturgy and in receiving Sacraments, as well as in the charity and social work for others. 


\section{The care for the marriage of a disabled person}

The pastoral care for the marriage of a disabled person is necessary even before the marriage is contracted. The proper preparation for the life in a marriage and family is of special importance for the permanence and development of the marriage bonds and for the fulfilment of the tasks by the spouses. Parish ministry is expected to ensure the proximate and immediate preparation for the Sacrament of marriage for the future spouses. The proximate preparation takes place during the extracurricular catechesis and the school catechesis. The school catechesis for disabled young people is provided in the special training and education centres as well as in the integrated education schools. During the catechization, young people learn about the theology of the Sacrament of marriage, the term and the meaning of the 'domestic church', the elements of the canon law on marriage and family life, the basic information of psychology of the marriage and family life, the issues connected with the ethics of the marriage and family life. In terms of education, the task of the school catechesis is to develop the skills useful for the implementation of the duties in the life in a marriage and family. The initiation dimension is related to the discovery of the community nature of Sacraments, especially the Eucharist. The catechized are introduced into the communion with God. and with other believers. through the liturgy and prayer'.

The catechesis addressed to young people with disabilities should show the specificity of the marriage and family of a person who is physically and intellectually disabled ${ }^{10}$. Showing the beauty of the vocation to live in a family and marriage, we should also show the limitations which are brought to the marriage and family life by disability. Young people should be aware of the fact that not every disabled person is capable of contracting a marriage and undertaking the duties that result from it ${ }^{11}$. They should also learn about the specific conditions of living in a marriage and family of those suffering from various types and levels of disability. During the catechesis, young people should learn about the characteristics of the marriage between people who are disabled with able-bodied people as well as about the

9 J. Kamiński, Przygotowanie do małżeństwa i życia w rodzinie w nauczaniu Kościoła katolickiego, "Roczniki Pastoralno-Katechetyczne" 2 (2010), p. 110.

10 See J. Stala, Katecheza specjalna wyrazem troski o każdego człowieka w świetle dokumentów synodalnych w Polsce po 1980 roku, in: Katecheza specjalna dzisiaj, ed. J. Stala, Kielce 2003, Jedność, p. 67-77.

11 This especially applies to people with a serious mental disability. 
marriages of two disabled people. Young disabled people should be prepared for a greater effort which they have to make in pursuing their vocation for the life in marriage and the family in comparison with the effort made by able-bodied people in marriage. In view of the life in a marriage and the family. the goal of the catechesis is to help a young person with a disability in a creative acceptance of his or her limitations.

Similarly to the able-bodied people, disabled people are supposed to attend the extracurricular catechesis in the parish. Such a catechesis is characterized by a deepened conveyance of the information concerning life in a marriage and family. It prepares for establishing and deepening the personal relationships in a marriage and family life. It also helps to develop the communal and religious life in a parish ${ }^{12}$. The catechesis which is meant for the disabled should emphasize their importance in a married and family life and it should draw their attention to the duties which result from the life in a marriage and family. A disabled person should be, to the extent that results from his or her limitations, a partner of the able-bodied person and should actively participate in building the marital community. His or her task is also to be subjectively involved in the life of the local parish community.

The immediate preparation for marriage is also of particular importance. It is individual and includes a meeting with the future spouses in the office of the parish priest, three prenuptial catechesis, at least three meetings in the family counselling centre, the confession before contracting the Sacrament of marriage and a conversation with a priest about the religious knowledge of the future spouses ${ }^{13}$. At this stage, it is checked whether there are any canonical obstacles to contracting the Sacramental marriage by a disabled person, and in case there are any doubts, they should be verified by a specialist. The main aim of the catechesis is to increase the awareness of the future spouses about building the marriage bonds, about procreation, upbringing children and doing the household chores. The catechesis should help the future spouses get to know each other better and, what is the most important, to get to know all the limitations resulting from the disability of one of them and the influence they exert on the planned life in a marriage and the family. The emotional engagement may be a hindrance and result in the couple not paying the appropriate attention to the effects of disability on the marriage. Thus, the aim of the catechesis is to help both partners work out a realistic image of their marriage.

12 J. Kamiński, Przygotowanie do małżeństwa i życia w rodzinie, p. 111.

13 Polish Bishops' Conference, Directory for the Pastoral Care of Families no. 27. 
The immediate preparation should motivate the future spouses to work on themselves. In the case of the disabled person, this means the commitment to continue their rehabilitation in all possible ways. When it concerns the able-bodied future spouses, their work on themselves aims at deepening their readiness to accept the additional burden, raising the awareness of the specific disability of the fiancé or fiancée and supporting him or her in his or her efforts of the revalidation. The able-bodied partner should also be aware of the prognosis concerning his or her condition and should be prepared to support the disabled partner in fulfilling his or her duties.

The immediate preparation for a marriage also concerns the issue of procreation ${ }^{14}$. In case of the disabled it concerns the issue of the possibility of conceiving a child by them and their willingness to have a child; rejection of a child is usually the cause of the nullity of the marriage. During the conversation with the priest, these issues must be introduced to the future spouses so that they were aware of their own limitations in this subject and the opinion of the fiancé or fiancée which concerns procreation and fertility.

In this context, the meaning of the issues concerning the ethics of life in a marriage and family is of greater significance than in case of a marriage of the able-bodied, especially such issues as the abortion and contraception. In this stage of preparation for the life in marriage, the role of the lay specialists is not to be undermined as they are those who should explain the theological and moral aspects and who inform the future spouses about the specific functioning of the body of a man and a woman, and show the specificity in the context of the incomplete physical or mental ability.

The parish pastoral care of the family should accompany young people also after they contract the Sacramental marriage. In their shaping of the marital bonds, couples including disabled people, especially when both spouses suffer from disability, face many additional problems. The discrepancy between the expectations and the reality is a common instance. When the fiancés get to know each other better, it may, in same cases, bring disappointment with the shared life and present new, unforeseen requirements. In such cases the young spouses need a support from the priests whose goals are to help solve the problems in the Christian spirit, in communion with Christ, with Whom they are united in the Sacrament of marriage. The preferable form of the pastoral help is the pastoral

14 See J. Goleń, Motywy zawarcia małżeństwa sakramentalnego. Studium z duszpasterstwa rodzin w świetle badań narzeczonych, Lublin 2013, Wydawnictwo KUL 2013, p. 67-74. 
visit in the houses of these families. At home, in the conducive atmosphere, young spouses feel more comfortable to openly talk to the priest and to accept the help he offers. Such visits may also be carried out by the employees of the parish pastoral care of the family centre. They have the advantage of not creating the atmosphere of formality, which is common in case of a visit paid by a priest. As a result, the help offered by the lay pastoral workers may be more effective ${ }^{15}$.

\section{The pastoral care of the family and the families with a disabled child}

The expected effectiveness of the pastoral support for a family with a disabled child requires a constant contact of the parish priests with such a family. Because of this, a parish needs to possess a list of the names of the families with disabled persons who live in the parish and their characteristics, with the particular attention to their needs and the forms of assistance provided so far. Such families require a constant pastoral care with the special engagement of the parish priest who is responsible for the pastoral care in his parish. However, the multiplicity and complexity of the needs indicate the necessary involvement of both the clergy and lay workers.

The basic form of the pastoral help for the family of a disabled person is a pastoral visit in such families. They provide the parish priests with necessary information about the living conditions of the family with the disabled members, of their needs and difficulties. It is important for the pastoral care priests to get to know the spiritual, material and psychological needs of such families. The aim of the pastoral care of the family is to respond to the different requirements of believers. Pastoral visits in families affected by disability lead a better response to the families' recognized needs. Visits in the families whose members (e.g. little children, people who are poorly rehabilitated or suffering from some additional diseases) have difficulty leaving the house, are of special importance.

Among the needs of the families who have a disabled child, material needs are the most important. The care and upbringing of a disabled child require more investment than the care for an able-bodied child. Though such families receive material aid from the state, such help is not always sufficient. Families with low income need the support from the parish in particular. In the first instance, the

15 D. Lipiec, Odwiedziny duszpasterskie rodzin, in: Duszpasterstwo rodzin, p. 427-429. 
assistance concerns a child suffering from a disability: such a child needs to be provided with money for the treatment, rehabilitation, additional training, etc. The family of the disabled child, as a small community, should also be provided with material help. The additional costs of upbringing and educating a disabled child are often taken at the expense of the other family members, including the able-bodied children, and they affect the running of the household to a great extent. For that reason the whole family should be regarded as affected by the disability and should be helped. The task of the parish Caritas team is primarily to help meet the material needs of the families of the children with disabilities.

Psychological aid and spiritual support should be among the most important tasks of the parish in its care for the families with disabled children. Such help is necessary from the very beginning, that is from the first moment when parents get the information that their child will suffer from disability. Parents are usually informed about that before the child is born. It is usually a shock for them, and the shock is accompanied by disbelief which further results in the lack of acceptance of the child's disability. The emotions are less violent when a child gradually loses the physical or mental capacity as a result of the disease. However, coming to terms with the deteriorating health of the child is a long and difficult process. In case of the child's disability the parents may feel a sense of guilt ${ }^{16}$.

The aim of the parish family counselling is to accompany the parents of a disabled child from the moment when they are informed about the disability of the newborn child or from the moment when the child becomes disabled. This kind of help is given by a priest or by a psychologist. Their aim is to accompany the parents in all the phases of the evolution of the feelings that accompany the parents who live with their child's disability. From despair the parents should be led to a constructive adaptation, characterized by the full acceptance of the child and his disability, it is a prerequisite for the proper care and education of the child.

Not all parents adopt the correct attitude towards disabled children. This is a real challenge for the parish pastoral care. Some parents adopt the attitude of denial which results from the lack of acceptance of the child. It results in creating an untrue image of the child and in imposing unrealistic demands on the child. Other parents become overprotective which results from exaggerating the child's disability and its consequences. Such parents limit the child's independence, which contributes to the difficulty in adapting to the independent living, and to shaping

16 See D. Rysiak, Postawy rodziców wobec dziecka niepetnosprawnego, "Nasze Dzieci” (2001) nr 2, p. 15-16. 
the attitude of dependence and helplessness of life. There are also parents who adopt the attitude of rejection of the child. They do not accept the child's disability and hide him or her from other people. The child who is brought up by such parents feels their negative attitude and this leads to creating the child's unstable emotional development. As a result of that, the child has difficulty in establishing relationships with other people and has a tendency to withdraw from life. An extreme form of the attitude of rejection is the public rejection. This happens when the parents openly reject the child and his or her disability. Because of the child's disability, the parents show their disinclination and sometimes even hostility and aggression ${ }^{17}$. The occurrence of such attitudes is a challenge for the parish pastoral care. The aim of the lay and spiritual care specialists is to help parents accept such a child and his or her disability.

The change in the parents' attitude towards their disabled child depends on the age of the parents, on the quality of their marital bonds and their religiousness ${ }^{18}$. In cases when a child becomes disabled, the aim of the parish family counselling is to strengthen the bonds between the parents. The mutual blaming of the parents for the child's disability, the shift in the ideal of marriage and family happiness, the additional burden of the new duties and other circumstances connected with upbringing and educating a disabled child negatively influence the strength and quality of these bonds. Priests and other pastoral care workers aim at providing the spiritual support to the parents and at helping them understand their situation and rebuild the positive image of their family as well as at helping them open up to each other and overcome these obstacles. The priests should also help the spouses in deepening their relationship with God. The strengthening of this bond leads to a better understanding of their own vocation for life in a marriage and family in the light of the Revelation. It also leads to redefine their position and role in the family, to the acceptance of suffering resulting from the disability and to sharing it with God. All these conditions are indispensable for the creative affirmation of the disabled child in the family and for creating proper relationships between the members of the family. This not only refers to the proper relationship between the parents but also the proper relationship between the disabled child and his

17 See Z. Sękowska, Przystosowanie społeczne młodzieży niewidomej, Warszawa 1991, WSiP, p. $38-39$.

18 See D. Osik, Rodzice w procesie socjalizacji dzieci niewidomych, Lublin 2000, Wydawnictwo UMCS, p. 55-56. 
siblings, and between the parents and the able-bodied children as they are also affected by their sibling's disability ${ }^{19}$.

A parish, due to the limited possibilities, can help the family in the upbringing and the rehabilitation of a disabled child only to a some extent. It should, however, provide the parents with the information about the institutions and the people who can effectively support them. Such institutions are: health departments, school and educational centres and information centres for people with disabilities. The aim of the parish pastoral care of the family centre is to help in the religious upbringing of a disabled child. Due to the fact that in Poland all the children, also those with a disability, have the possibility to attend the school catechesis, it is extremely important to provide the proper preparation for the Sacraments: the Eucharist, Penance and Confirmation.

This is particularly important for children who are to receive these Sacraments in their parish; in cases where a child is in an educational centre, he or she often receives them in a group of his disabled peers. The preparation of a disabled child to receive the Sacraments is usually on an individual basis. Such a child usually needs more time to acquire the theoretical knowledge and the practical skills which are necessary to receive the Sacraments in their future life. The effects of the preparation also depend on the collaboration of the priests and catechists with the parents. This means that the preparation should be extended to both students and their parents ${ }^{20}$.

Although a parish is the smallest part of the Church, it can effectively help the families of disabled people in a variety of ways. Through the parish Caritas group it can partly satisfy the material needs, offering financial support and some necessary goods. In the parish family counselling centre, the disabled and their families can receive help from a psychologist, a counsellor, a doctor, a lawyer and other specialists. Such help is offered to either the people who live in a marriage and family or to those who are preparing for these. In cases when the needs of

19 See M. Komorska, Sytuacja dzieci i młodzieży niepełnosprawnej w społeczeństwie polskim, Lublin 2000, Wydawnictwo UMCS, p. 95.

20 See D. Lipiec, Uwarunkowania i kierunki współpracy katechety z rodzicami dziecka z uszkodzonym wzrokiem, in: W poszukiwaniu katechezy rodziców. Studium teoretyczno-empiryczne, Ed. J. Stala, E. Osewska, Tarnów 2007, Biblos, p. 346-348. 
a disabled person go far beyond the parish counselling centre's possibilities of fulfilment, it is the task of the parish priests to send these people to specialists.

\section{Bibliography}

Bartoszek A., Sitko D. (eds.), Osoby niepełnosprawne w życiu społeczeństwa i Kościoła, KatowiceTarnów 2003, Biblos.

Buchta R., Sosna K. (eds.), Etyczne i duchowe potrzeby osób niepełnosprawnych, Katowice 2007, Księgarnia św. Jacka.

Brzezinka Z. (ed.), Dialog z osobami niepetnosprawnymi, Katowice 2004: Kuria Metropolitalna, Wydział Katechetyczny.

Czaja A. M., Podstawy kanonicznej wiedzy o małżeństwie i rodzinie, Lublin 2008, Polihymnia.

Lipiec D., Duszpasterstwo rodzin osób niepełnosprawnych, "Roczniki Pastoralno-Katechetyczne" 3 (2001), p. 363-378.

Majewski T., Poradnik metodyczny dla nauczycieli pracujacych $z$ dziećmi z uszkodzonym wzrokiem w systemie i integracyjnym, Warszawa 1997, MEN.

Pyźlak G., Duszpasterstwo wobec współczesnych zagrożeń rodziny, "Roczniki Teologiczne" 55 (2008) z. 6, p. 223-234.

Pyźlak G., Troska duszpasterstwa rodzin o narzeczonych, "Roczniki Pastoralno-Katechetyczne" 4 (2012), p. 103-114.

Stala J., Katecheza specjalna wyrazem troski o każdego człowieka w świetle dokumentów synodalnych w Polsce po 1980 roku, in: Katecheza specjalna dzisiaj, J. Stala (ed.), Kielce 2003, Jedność, p. 67-77. 